\title{
Pemenuhan Hak atas Informasi Publik sebagai Tanggung Jawab Negara dalam rangka Mewujudkan Good Governance
}

\author{
Adam Muhshi \\ University of Jember, Indonesia \\ adammuhshi.fh@unej.ac.id
}

\begin{abstract}
There are two legal issues proposed in this study, inter alia, the nature of the right to public information and state's responsibility for the fulfillment of the right to public information. This study uses legal research with statute and conceptual approaches. The results of this study shows that the right to public information becomes part of the human rights as guaranteed by the 1945 Constitution. Public information has become a logical consequence of the obligation of the state to account for the implementation of its government to the citizens as its main purpose is to ensure the accountability and credibility of public institutions through the provision of information and documents at the public request so that the principle of information disclosure is one component in the realization of good governance. As a constitutional right of citizens, it also shows that 'a contrario' the fulfillment of public information is the responsibility of the state. According to this view, the fulfillment of the right to public information is not only related to obligations, but the content must be true and provided openly and honestly. It concludes that the fulfillment of public information conducted openly and honestly will contribute to an attempt to realize good governance
\end{abstract}

KEYWORDS: Human Rights, Public Information, Good Governance.

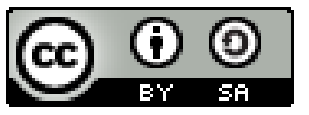

Copyright $\odot 2018$ by Author(s)

International License All writing licensed under a Creative Conmons Attribution ShareAlike 4.0 not represent the views of this journal and the author's affiliated institutions.

\section{HOW TO CITE:}

Muhshi, Adam. "Pemenuhan Hak atas Informasi Publik sebagai Tanggung Jawab Negara dalam rangka Mewujudkan Good Governance" (2018) 5:1 Lentera Hukum 63-76.

Submitted: March 25, 2018 Revised: April 12, 2018 Accepted: April 23, 2018 


\section{PENDAHULUAN}

Indonesia merupakan negara hukum yang demokratis. Hal ini tercermin dari pengakuan kedaulatan rakyat yang dilaksanakan menurut Undang-Undang Dasar (UUD). Konsep ini ditegaskan pada Pasal 1 ayat (2) Undang-Undang Dasar Negara Republik Indonesia Tahun 1945 (UUD NRI 1945) yang menentukan, "Kedaulatan berada di tangan rakyat dan dilaksanakan menurut Undang-Undang Dasar". Ketentuan tersebut selain menegaskan adanya pengakuan terhadap kedaulatan rakyat, sekaligus menunjukkan adanya kedaulatan hukum yang secara implisit ditandai oleh frase "menurut Undang-Undang Dasar". Keberadaan kedaulatan hukum itu kemudian dipertegas lagi oleh Pasal 1 ayat (3) UUD NRI 1945 yang menentukan bahwa: "Negara Indonesia adalah negara hukum".

Sebagai sebuah negara hukum yang demokratis, tata kelola dan penyelenggaraan pemerintahan Indonesia harus selalu didasarkan pada prinsip transparansi dan akuntabilitas. ${ }^{2}$ Salah satu elemen esensial dari tata kelola pemerintahan yang transparan dan akuntabel tersebut adalah adanya pelayanan keterbukaan informasi publik. ${ }^{3}$ Oleh sebab itu, reformasi konstitusi (1999-2000) telah menetapkan hak masyarakat untuk memperoleh informasi secara terbuka dan jujur dari lembagalembaga negara dan dari instansi-instansi pemerintah sebagai bagian dari Hak-hak Asasi Manusia (HAM) yang dijamin oleh UUD NRI $1945 .^{4}$

Dengan demikian dapat dikatakan bahwa dalam negara hukum demokrasi Indonesia, pemerintah harus dapat mempertanggungjawabkan pelaksanaan tugas dan kewajibannya kepada rakyat. Oleh karena itu, menjadi logis kemudian ketika rakyat memiliki hak untuk mengetahui informasi-informasi mengenai kinerja atau penyelenggaraan pemerintahan tersebut. ${ }^{5}$ Secara a contrario, pemenuhan hak atas informasi publik menjadi tanggung jawab negara, pemerintah. Hal ini berarti bahwa keterbukaan informasi publik berfungsi sebagai salah satu saluran pertanggungjawaban pemerintah kepada rakyat atas kinerjanya.

Akan tetapi, dalam implementasinya, hak atas informasi publik yang telah dijamin oleh konstitusi dan kemudian diderivasi ke dalam Undang-Undang Nomor 14 Tahun 2008 tentang Keterbukaan Informasi Publik (untuk selanjutnya disebut UU KIP) tidaklah mudah karena seperti dikatakan Suko Widodo, ia menghadapi banyak kendala baik yang bersifat stuktural maupun kultural. ${ }^{6}$ Lebih lanjut, Suko Widodo mengatakan bahwa birokrasi yang memiliki akar sejarah dari kultur feodal

\footnotetext{
Adam Muhshi, Meninjau Ulang Kriteria Legal Standing dalam Hukum Acara MK (Jember, 2016) hlm. l.

"Panduan Mengenal Hak atas Informasi Publik dan Pemolisian", online: 〈https://www.kontras.org/buku/ PEMOLISIAN\%20OK.pdf〉 hlm. 5.

4 Mohammad Mahfud MD, Kedudukan Komisi-Komisi Negara dalam Sistem Ketatanegaraan Kita, dalam MZ Al-Faqih, "Komisi Informasi Reposisi dan Penguatannya" in (Yogyakarta: Deepublish, 2017) hlm. 14.

5 Endang Retnowati, "Keterbukaan informasi publik dan good governance (Antara das sein dan das sollen)" (2012) 17:1 Perspektif 54 hlm. 54.

6 Suko Widodo, "UU Keterbukaan Informasi Publik antara Harapan dan Kenyataan" (2016) 1:2 KANAL J Ilmu Komun 131 hlm. 132.
}

Ibid. 
menanamkan nilai-nilai yang tidak kondusif bagi sistem pelayanan yang lancar dan transparan. ${ }^{7}$ Warisan kultural seperti itu mengalami penguatan pada rezim pemerintahan otoriter masa Orde Baru, sehingga birokrasi tampil begitu perkasa dan kultur pelayanan publik tidak berkembang. ${ }^{8}$

Persoalan implementatif tersebut, tentu saja, telah didukung pula oleh adanya ketentuan bahwa tidak semua informasi publik itu dapat diperoleh oleh warga negara. Pembatasan ini tentu saja akan memberi peluang kepada negara untuk tidak mengeluarkan informasi publik yang sebenarnya harus dibuka atau diberikan pada warga negara. Pertanyaan yang dapat diajukan kemudian adalah perlukah dilakukan pembatasan terhadap pemenuhan hak atas informasi publik dan apakah pembatasan ini tidak bertentangan dengan keberadaan informasi publik sebagai bagian dari HAM. Hal-hal tersebut merupakan persoalan penting untuk dicari jawabannya guna mengetahui hakikat mengapa informasi publik menjadi bagian dari HAM dan apa pula implikasinya bagi negara dalam rangka pemenuhan hak atas informasi publik tersebut.

Berdasarkan sedikit uraian tersebut, tulisan ini akan mengkaji hak warga negara untuk mendapatkan informasi publik berdasarkan UUD NRI 1945. Isu hukum hak warga negara untuk mendapatkan informasi publik akan dikaji dengan menjawab dua permasalahan hukum yang terkait dengan isu hukum tersebut, yaitu mengenai hakikat hak atas informasi publik dan tanggung jawab negara terhadap pemenuhan hak atas informasi publik.

\section{HAKIKAT HAK ATAS INFORMASI PUBLIK}

Bicara tentang hakikat hak atas Informasi publik sangat terkait dengan pertanyaan mengapa informasi publik itu menjadi hak dan perlu dilindungi secara hukum. ${ }^{9}$ Berdasarkan pertanyaan tersebut dapat disampaikan bahwa lahirnya konsep hak sebenarnya dibidani oleh dua konsep kunci yaitu keadaan alamiah dan perjanjian masyarakat. ${ }^{10}$ Keadaan alamiah melahirkan sebuah gagasan bahwa manusia sejak dilahirkan telah disertai dengan hak alamiah berupa kebebasan. ${ }^{11}$ Sedangkan konsep perjanjian masyarakat (kontrak sosial) melahirkan sebuah gagasan bahwa individuindividu menyerahkan sebagian kebebasannya kepada penguasa untuk melindungi hak alamiah tersebut demi terciptanya ketertiban. ${ }^{12}$ Dua konsep kunci tersebut memberikan suatu pengertian bahwa legitimasi kekuasaan berasal dari perjanjian.

\footnotetext{
Ibid.

Ibid.

Harjono menyampaikan bahwa masyarakat hukum dengan sistem hukumnya menentukan kepentingan-kepentingan apa saja dari anggota masyarakatnya yang dapat ditingkatkan menjadi hakhak hukum sehingga kemudian dapat dipaksakan pemenuhannya. Konstruksi pemikiran itu kemudian membentuk konsep perlinduangan hukum yang ia artikan sebagai perlindungan dengan menggunakan sarana hukum atau perlindungan yang diberikan oleh hukum. Baca lebih lanjut Harjono, Konstitusi sebagai Rumah Bangsa; Pemikiran Hukum Dr. Harjono, S.H., M.C.L. Wakil Ketua MK (Jakarta: Sekretariat Jenderal dan Kepaniteraan Mahkamah Konstitusi, 2008) hlm. 375-378.

10 LG Saraswati et al, Hak Asasi Manusia; Teori, Hukum, Kasus (Jakarta: Filsafat UI Perss, 2006) hlm. 68.

11 Ibid.

12 Ibid.
} 
Dengan demikian, setiap orang tidak dapat dipaksa oleh kekuasaan, kecuali kekuasaan sudah mendapat persetujuan dari masyarakat. ${ }^{13}$

Sebelum negara terbentuk, manusia hidup dalam keadaan bebas atau keadaan alamiah (state of nature atau status naturalis). Menurut John Locke, dalam keadaan alam bebas itu manusia telah memiliki hak-hak alamiah yang dimilikinya secara pribadi, yaitu berupa hak hidup, hak atas kebebasan atau kemerdekaan, dan hak milik. ${ }^{14}$ Jadi menurut kodratnya, manusia itu sejak lahir telah memiliki hak-hak kodrat atau hakhak alamiah. ${ }^{15}$

Permasalahan yang kemudian timbul dalam keadaan alam bebas itu adalah bahwa hak-hak alamiah itu tidak dapat dilaksanakan dengan baik. Hal ini disebabkan oleh keinginan tiap individu untuk membela kepentingannya masing-masing tanpa memperdulikan kepentingan dari orang lain. Sedangkan di sisi lain belum ada kepastian hukum, sehingga berakibat ketertiban hukum tidak dapat dilaksanakan. Dalam status naturalis tersebut, manusia akan terlibat dalam perang antara semua melawan semua (bellum omnius contra omnes/the war of all againts all) demi mengejar kepentingannya masing-masing. Individu-individu akan saling membinasakan. Keadaan inilah yang oleh Thomas Hobbes ${ }^{16}$ disebut dengan homo homini lupus, yaitu manusia yang satu merupakan serigala bagi manusia yang lainnya.

Untuk itulah, individu-individu tersebut kemudian menyelenggarakan suatu perjanjian masyarakat (pactum unionis) untuk membentuk masyarakat politik atau negara. ${ }^{17}$ Berdasarkan perjanjian tersebut, individu-individu menyerahkan sebagian hak-hak alamiahnya kepada masyarakat. Kemudian masyarakat menunjuk seorang penguasa yang kepadanya diberi suatu kewenangan untuk menjaga dan menjamin terlaksananya hak-hak alamiah dari tiap-tiap individu. Dengan tujuan pemberian kekuasaan tersebut, maka berarti bahwa kewenangan tersebut terbatas yaitu dibatasi oleh hak-hak alamiah tiap individu. Atau dengan kata lain penguasa tidak boleh melanggar hak-hak dasar individu karena menurut John Locke $^{18}$ tujuan utama diadakannya perjanjian masyarakat dalam membentuk negara adalah untuk mempertahankan hak-hak asasi.

Setelah penyerahan kemerdekaan alamiah tiap-tiap individu kepada suatu organisasi yang bernama negara tersebut, kemudian di bawah organisasi itu pula mereka mendapatkan kembali kemerdekaan sipilnya, yaitu kemerdekaan berbuat segala sesuatu dengan syarat masih dalam koridor hukum yang berlaku (freedom under

13 Adam Muhshi, Teologi Konstitusi; Hukum Hak Asasi Manusia atas Kebebasan Beragama di Indonesia (Yogyakarta: LKiS, 2015) hlm. 39-40.

14 Soehino, Ilmu Negara (Yogyakarta: Liberty, 1998) hlm. 107-108.

15 Philipus M Hadjon, Perlindungan Hukum bagi Rakyat di Indonesia; Sebuah Studi dan Prinsip-Prinsipnya, Penanganannya di Pengadilan dalam Lingkungan Peradilan Umum dan Pembentukan Peradilan Administrasi, edisi khusus ed (Peradaban, 2007) hlm. 35.

16 Baca pendapat Hobbes tersebut dalam Bernard L Tanya, ahmad nasir \& Paijo Jawa, Teori Hukum; Strategi Tertib Manusia Lintas Ruang dan Generasi (Yogyakarta: Genta Publishing, 2010) at 66.

17 Ni 'matul Huda, Ilmu Negara (Jakarta: Rajawali Pers, 2011) hlm. 43.

18 Azhary, Ilmu Negara: Pembahasan Buku Prof. Mr. R. Krannenburg (Jakarta: Ghalia Indonesia, 1986) hlm. 18. 
the rule of law). Yang berdaulat dalam organisasi yang disebut negara ini adalah rakyat, sedangkan pemerintah hanya dalam kapasitas mewakili rakyat. Konsekuensinya adalah bahwa apabila pemerintah tidak menjalankan kekuasaannya sesuai dengan kehendak rakyat, maka pemerintah itu harus diganti. ${ }^{19}$

Berdasarkan konstruksi perjanjian masyarakat seperti itu, J.J. Rousseau telah menghasilkan bentuk negara yang kedaulatannya berada dalam tangan rakyat melalui kemauan umum. ${ }^{20}$ Dengan demikian J.J. Rousseau merupakan pencetus paham atau teori kedaulatan rakyat yang berlandaskan pada apa yang disebut dengan volonte generale (kehendak umum). ${ }^{21}$ J.J. Von Schmid ${ }^{22}$ menyatakan bahwa volonte generale itu ditujukan kepada kepentingan umum. Tapi di sisi lain ada volunte de tous yang ditujukan kepada kepentingan semua orang tetapi orang-orang itu tidaklah merupakan suatu kesatuan, atau dengan kata lain kepentingan dari semua orang secara individual. ${ }^{23}$

Dari pemikiran tersebut, maka perlu dipahami bahwa penguasa dalam hal ini selain harus melindungi kepentingan umum juga harus melindungi kepentingan semua orang secara individual. Konsekuensinya, penguasa dalam menjalankan hak atau wewenangnya dalam rangka menjaga keutuhan negara tidak boleh mengabaikan dan/atau melanggar hak warga negaranya. Dengan demikian, salah satu kewajiban yang sangat penting dengan adanya negara adalah untuk melindungi rakyatnya berdasarkan hukum yang berlaku dalam negara yang bersangkutan. ${ }^{24}$

Berdasarkan teori perjanjian masyarakat sebagaimana dipaparkan di atas, maka dapat dipahami bahwa terbentuknya negara berdasarkan perjanjian masyarakat tersebut, melahirkan relasi atau hubungan antara negara itu sendiri dengan rakyatnya. Hubungan negara dan rakyat tersebut menimbulkan sebuah konsekuensi logis berupa tujuan negara untuk melakukan perlindungan terhadap hak asasi manusia. Hal ini sesuai dengan pendapat John Locke sebagaimana telah disampaikan di atas yang menyatakan bahwa tujuan utama diadakannya perjanjian masyarakat adalah membentuk negara guna melindungi hak-hak asasi. ${ }^{25}$ Guna mencapai tujuan negara dalam melindungi hak asasi manusia tersebut, maka diperlukan adanya fungsi negara yang harus dijalankan. Hal ini sesuai dengan apa yang dinyatakan Kusnardi dan Bintan R. Saragih, yaitu bahwa fungsi negara diartikan sebagai tugas daripada organisasi negara untuk mana negara itu diadakan. ${ }^{26}$

Berbicara tentang fungsi negara, ada beberapa teori fungsi negara yang yang dikemukakan oleh para ahli seperti misalnya Charles E. Merriam, John Locke,

19 Muhshi, supra note $13 \mathrm{hlm} .31$.

20 Baca lebih lanjut pendapat Rousseau tersebut dalam Ni 'matul Huda, Lembaga Negara dalam Masa Transisi Demokrasi (Yogyakarta: UII Perss, 2007) at 43.

21 Baca lebih lanjut pendapat Rousseau tersebut dalam Soehino, supra note 14 at 122.

22 Ibid.

23 Ibid.

24 Muhshi, supra note $13 \mathrm{hlm} .32$.

25 Azhary, supra note 18 at 18.

26 Kusnardi \& Bintan R Saragih, Ilmu Negara (Jakarta: Gaya Media Pratama, 2000) hlm. 221. 
Montesquieu, Van Vollenhoven, dan Goodnow. ${ }^{27}$ Dalam perkembangannya menurut Hendra Nurtjahjo gagasan yang paling sering menjadi acuan adalah teori Trias Politica dari Montesquieu. ${ }^{28}$ Gagasan trias politica tentang adanya pemisahan kekuasaan berdasarkan fungsi-fungsi utama negara, yaitu eksekutif, legislatif, dan yudisial selalu menjadi rujukan dalam negara hukum modern. Meskipun dalam pelaksanaannya akan bervariasi pada tiap-tiap negara. ${ }^{29}$

Teori trias politica erat kaitannya dengan pengembangan konsep negara hukum (rechtsstaat atau rule of law) dan konsep demokrasi (goverment or rule by the people). Pemisahan kekuasaan ke dalam badan legislatif, eksekutif, dan yudisial berkaitan dengan konsep checks and balances yang pada gilirannya akan mengawal penyelenggaraan suatu negara hukum yang demokratis. Dengan demikian dapat dikatakan bahwa fungsi negara erat kaitannya dengan konsep negara hukum dan konsep demokrasi. Dalam konteks negara hukum, fungsi negara adalah dalam rangka melakukan perlindungan hukum bagi rakyat. Sedangkan dalam konteks demokrasi, fungsi negara adalah dalam rangka menegakkan kebebasan dan persamaan. ${ }^{30}$

Sebagai manifestasi dari demokrasi, HAM mengandung esensi berupa hak akan kebebasan dan persamaan. Artinya bahwa dalam konteks demokrasi, kebebasan dan persamaan tersebut merupakan hak yang melekat pada manusia sejak lahir dan tidak dapat dicabut darinya. Pemikiran seperti itulah yang kemudian mendasari ketentuan Pasal 1 Deklarasi Universal Hak Asasi manusia 1948 (DUHAM) yang oleh LG. Saraswati $\mathrm{dkk}^{31}$ diangap mendefinisikan dasar filosofis Hak Asasi Manusia. DUHAM mencerminkan suatu tingkat perkembangan kesadaran yang cukup menentukan karena mengakui bahwa semua manusia dilahirkan bebas dan sama. Terkait hal ini, Pasal 1 DUHAM menyatakan bahwa: "All human beings are born free and equal in dignity and rights. They are endowed with reason and conscience and should act towards one nother in a spirit of brotherhood (Semua manusia dilahirkan bebas dan setara dalam hal martabat dan hak. Mereka dikaruniai akal dan hati nurani dan harus bertindak dalam semangat

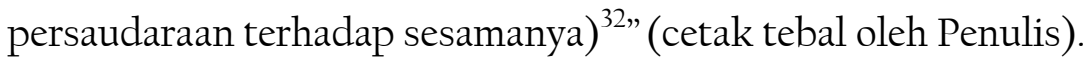

Hak atas kebebasan dan persamaan tersebut tentu saja meliputi hak atas informasi publik yang merupakan bagian dari hak asasi manusia. Dalam instrumen hukum internasional, hak untuk memperoleh informasi diatur dalam Resolusi Umum PBB Nomor 59 ayat (1) Tahun 1946 yang menyatakan bahwa kebebasan informasi merupakan hak asasi yang fundamental dan sebagai tanda dari seluruh kebebasan yang akan menjadi titik perhatian PBB. ${ }^{33}$ Dalam hal ini Pasal 19 Deklarasi Universal Hak Asasi manusia (DUHAM) dan Pasal 19 Konvensi Hak Sipil dan Politik menentukan

27 Baca lebih lanjut Muhshi, supra note 13 hlm. 33-35.

Ibid hlm. 35.

Ibid.

30 Ibid hlm. 36.

31 Saraswati et al, supra note $10 \mathrm{hlm} .2$.

32 Terjemahan dari penulis.

33 Toby Mendel dalam Nunuk Febriananingsih, "Keterbukaan Informasi Publik dalam Pemerintahan Terbuka Menuju Tata Pemerintahan yang Baik" (2012) l:1 Rechtsvinding 135 hlm. 136. 
bahwa setiap orang memiliki hak atas kebebasan untuk mengemukakan pendapat dan gagasan; dimana hak tersebut meliputi hak untuk memegang pendapat tanpa ganguan dan campur tangan, dan untuk mencari, menerima serta menyebarkan informasi dan gagasan melalui media apapun tanpa mempertimbangkan garis batas negara.

Sebagai bagian dari HAM yang bersifat universal, maka sudah selayaknya hak atas informasi publik kemudian dimasukkan sebagai salah satu hak konstitusional dalam UUD NRI 1945. Hal ini juga sebagai konsekuensi logis keberadaan konstitusi yang merupakan titik temu antara konsep negara hukum dan konsep demokrasi sehingga materi muatannya haruslah berisi tentang adanya kebebasan warga negara serta adanya pembatasan terhadap kekuasaan agar tidak terjadi pelanggaran terhadap HAM. $^{34}$

Berdasarkan uraian tentang lahirnya negara berdasarkan perjanjian masyarakat di atas, diketahui bahwa yang berdaulat dalam organisasi yang disebut negara tersebut adalah rakyat, sedangkan pemerintah hanya dalam kapasitas mewakili rakyat. Oleh sebab itu, negara kemudian harus dapat mempertanggungjawabkan pelaksanaan tugas dan kewenangannya kepada rakyat. Konsekuensi logisnya adalah bahwa rakyat memiliki hak untuk mengetahui informasi-informasi mengenai kinerja atau penyelenggaraan pemerintahan tersebut. Dengan demikian dapat dikatakan bahwa fungsi keterbukaan informasi publik adalah sebagai salah satu saluran pertanggungjawaban pemerintah kepada rakyat atas kinerjanya.

Terkait hal itu, Bolton mengatakan bahwa pada prinsipnya tujuan utama keterbukaan informasi publik di setiap negara adalah untuk memastikan bahwa lembaga publik akan lebih akuntabel dan kredibel dengan menyediakan informasi dan dokumen sesuai permintaan publik. ${ }^{35}$ Oleh sebab itu, dapat dikatakan bahwa prinsip keterbukaan informasi sebagai salah satu komponen dalam mewujudkan tata pemerintahan yang baik (good governance). ${ }^{36}$

Tujuan untuk mewujudkan tata pemerintahan yang baik (good governance) ${ }^{37}$ dari adanya keterbukaan informasi publik tersebut menemukan relevansinya dalam konteks negara hukum yang demokratis. Hal ini sesuai dengan pendapat Philipus M. Hadjon yang menyatakan bahwa permasalahan instrumen hukum utama dalam mewujudkan

\footnotetext{
Muhshi, supra note 13 hlm. 37.

Retnowati, supra note 5 hlm. 55.

Ibid.

37 Jimly Asshiddiqie mengatakan bahwa good governance sering diterjemahkan ke dalam bahasa Indoenesia menjadi tata kepemerintahan yang baik. Tujuan good governance tidak hanya pemerintahan yang bersih, namun juga harus memenuhi standar-standar kebaikan tertentu. Ia menambahkan bahwa tuntutan untuk mewujudkan good governance muncul seiring dengan kritik terhadap birokrasi pemerintahan yang berkembang tak terkendali dan memasuki semua wilayah kehidupan masyarakat sehingga terjadi masyarakat hiperregulasi. Baca lebih lanjut Jimly Asshiddiqie, Menuju Negara Hukum yang Demokratis (Jakarta: Sekretariat Jenderal dan Kepaniteraan Mahkamah Konstitusi, 2008) hlm. 45-46.
} 
good governance, pada hakikatnya adalah fungsi hukum tata negara dan hukum administrasi dalam mewujudkan asas negara hukum dan asas demokrasi. ${ }^{38}$

Dengan adanya transparansi atas informasi publik tentang kinerja pemerintah dalam melaksanakan penyelenggaraan negara atau pemerintahaannya, membuat masyarakat dapat ikut berpartisipasi aktif mengontrol setiap langkah dan kebijakan yang diambil pemerintah. Sehingga penyelenggaraan pemerintahan dapat dipertanggungjawabkan kepada rakyat. ${ }^{39}$ Perlunya partisipasi aktif dari masyarakat tersebut sebagai konsekuensi logis dari salah satu karakterisitik good governance ${ }^{40}$ seperti yang disampaikan oleh United Nations Development Programe (UNDP), yaitu prinsip participation. $^{41}$

\section{TANGGUNG JAWAB NEGARA}

Sebagai sebuah hak warga negara, maka secara a contrario pemenuhan hak atas informasi publik menjadi tanggung jawab negara. Pelaksanaan tanggung jawab terhadap pemenuhan hak informasi publik ini tentu saja tidak hanya sekedar gugur kewajiban, akan tetapi di dalamnya terkandung esensi bahwa informasi publik tersebut harus disampaikan dengan baik dan benar baik dari segi prosedur maupun dari segi substansinya.

Terkait dengan prosedur penyampaian dan isi dari informasi publik yang baik dan benar tersebut, Moh. Mahfud MD menyatakan bahwa tanggung jawab negara antara lain dengan memberikan informasi yang jujur ${ }^{42}$ dan dilakukan secara terbuka dan jujur pula. ${ }^{43}$ Hak untuk mendapatkan informasi secara terbuka dan jujur tersebut merupakan bagian dari hasil amandemen konstitusi (1999-2000) yang kemudian dituangkan ke dalam Pasal 28F UUD NRI 1945. ${ }^{44}$

38 Philipus M. Hadjon, Hukum Administrasi sebagai Instrumen Hukum untuk Mewujudkan Good Governance, dalam Muhadi, "Hukum Administrasi dan Good Governance" in (Jakarta: Universitas Trisakti, 2010) at 5.

39 Retnowati, supra note $5 \mathrm{hlm} .55$.

40 United Nations Development Programme (UNDP) sebagaimana dikutip oleh Lembaga Administrasi Negara menyebutkan beberapa unsur dari good governance, yaitu participation, rule of law, tranparency, responsiveness, concensus orientation, equity, effectiveness and effeciency, accountability, dan strategic vision. Baca lebih lanjut Muhadi, supra note $37 \mathrm{hlm}$. 38-40; Sedangkan United Kingdom Overseas Development Administration (UK/ODA) menyampaikan empat karakteristik good governance, yaitu legitimasi, akuntabilitas, kompetensi, dan penghormatan terhadap hukum / HAM. Baca lebih lanjut Asshiddiqie, supra note $36 \mathrm{hlm}$. 666; Terkait dengan unsurunsur good governance tersebut, G.H. Addink menyebutkan dalam bukunya bahwa ia terdiri dari: kepatutan, transparansi, partisipasi, efektivitas, akuntabilitas dan hak asasi manusia. Baca lebih lanjut GH Addink, Kepemerintahan yang Baik (Utrecht University, 2013) hlm. 7.

41 Paulus Effendie Lotulung, Tata Kepemerintahan yang Baik (Good Governance) dalam Korelasinya dengan Hukum Administrasi, dalam Muhadi, supra note 37 hlm. 38.

42 Moh. Mahfud MD, Kedudukan Komisi-Komisi Negara dalam Sistem Ketatanegaraan Kita, dalam AlFaqih, supra note 4 hlm. 14.

43 Moh. Mahfud MD, Kedudukan Komisi-Komisi Negara dalam Sistem Ketatanegaraan Kita, dalam ibid hlm. 17.

44 Moh. Mahfud MD, Kedudukan Komisi-Komisi Negara dalam Sistem Ketatanegaraan Kita, dalam ibid. 
Pasal 28F UUD NRI 1945 menentukan bahwa setiap orang dijamin haknya untuk berkomunikasi dan memperoleh informasi dalam rangka mengembangkan pribadi dan lingkungan sosialnya. Lebih dari itu, setiap orang dijamin haknya untuk mencari, memperoleh, memiliki, menyimpan, mengolah, serta menyampaikan informasi dengan menggunakan semua jenis saluran yang tersedia.

Jaminan konstitusional terhadap hak atas informasi publik tersebut kemudian diatur lebih lanjut ke dalam UU KIP. Kehadiran UU KIP tentu saja sebagai konsekuensi logis dari pilihan bangsa Indonesia atas bangunan negara yang demokratis. Dikatakan demikian karena hak atas informasi publik yang merupakan bagian dari HAM adalah sebagai salah satu ciri penting dari negara demokratis yang menjunjung tinggi kedaulatan rakyat dalam rangka mewujudkan penyelenggaraan negara yang baik. $^{45}$

Berdasarkan konstruksi berpikir tersebut, tidaklah berlebihan ketika Moh. Mahfud MD menyatakan bahwa UU KIP dimaksudkan untuk memperkuat pembangunan good governance yang menjadi suatu hal yang tidak bisa ditawar lagi keberadaannya dalam penyelenggaraan negara yang menganut prinsip dan sistem demokrasi. $^{46}$ oleh karena itu, Ia mengatakan lebih lanjut bahwa kelahiran Komisi Informasi dan keterbukaan informasi publik harus dipandang sebagai bagian dari upaya membangun good governance. ${ }^{47}$

Pendapat Moh. Mahfud MD tersebut, relevan ketika dikorelasikan dengan teori konstitusi sebagai produk perjanjian masyarakat yang merupakan titik temu antara konsep negara hukum dan negara demokrasi. ${ }^{48}$ Sebagai sebuah titik temu dari prinsip negara hukum dan demokrasi, maka materi muatan konstitusi haruslah berisi tentang adanya kebebasan warga negara di bawah jaminan konstitusi itu sendiri serta adanya pembatasan kekuasaan negara yang menentukan fungsi lembaga-lembaga negara agar tidak terjadi pelanggaran terhadap HAM. ${ }^{49}$

HAM yang menjadi tujuan dibentuknya sebuah konstitusi tersebut menurut Philipus M. Hadjon sangat erat hubungannnya dengan good governance. ${ }^{50}$ Dikatakan demikian karena konstitusi itu sendiri adalah sebagai unsur pokok hukum tata negara ${ }^{51}$

45 Baca konsideran menimbang huruf b UU KIP.

46 Al-Faqih, supra note 4 hlm. 14.

47 Ibid.

48 Hal ini berarti bahwa konstitusi sebagai manifestasi perjanjian masyarakat yang tertinggi menghendaki adanya pembatasan kekuasaan berdasarkan hukum guna menjamin adanya pengakuan dan perlindungan terhadap hak asasi manusia yang berpijak pada prinsip kebebasan dan persamaan. Baca lebih lanjut Adam Muhshi, "Teologi Konstitusi; Hak Warga Negara atas Kebebasan Beragama berdasarkan UUD NRI 1945” (2013) II:1 J Konstitusi Pus Kaji Konstitusi Univ Dr Soetomo Surabaya Kerjasama Dengan Mahkamah Konstitusi Repub Indones 7 hlm. 37.

49 Muhshi, supra note $13 \mathrm{hlm} .37$.

50 Muhadi, supra note 37 at 10; Sementara G.H. Addink mengatakan bahwa hubungan erat antara HAM dan good governance merupakan hak subjektif atas administrasi yang baik. Hak atas administrasi yang baik muncul sebagai suatu hak fundamental baru dan hak tersebut beralku bagi tiap orang yang melakukan kontak dengan lembaga pemerintahan. Baca lebih lanjut Addink, supra note 39 hlm. 8.

51 Baca lebih lanjut Moh Mahfud MD, Dasar dan Struktur Ketatanegaraan Indonesia (Yogyakarta: Penerbit UII Perss, 1993) hlm. 80. 
dan hukum administrasi, di mana dikatakan oleh Philipus M. Hadjon bahwa hukum tata negara dan hukum administrasi berfungsi untuk melindungi HAM berkenaan dengan penggunaan kekuasaan dan berkenaan dengan perilaku aparat dalam pelaksanakan pelayanan kepada masyarakat. ${ }^{52}$ Sedangkan Pelayanan kepada masyarakat ini sendiri merupakan sasaran dari good governance, dimana dalam hal ini Jimly Asshiddiqie menyatakan bahwa good governance salah satu tujuan utamanya dalah dalam rangka menciptakan tatanan kehidupan berbangsa dan bernegara yang mampu melayani kepentingan rakyat secara adil dan beradab. ${ }^{53}$

Dengan dimasukkannya hak atas informasi sebagai bagian HAM yang diatur dalam konstitusi, maka konsekuensi yuridisnya adalah timbulnya tanggung jawab negara terhadap pemenuhannya. Hal ini sesuai dengan Pasal 28I ayat (4) UUD NRI 1945 yang menentukan bahwa tanggung jawab terhadap pemenuhan HAM termasuk dalam hal ini, hak atas informasi publik, diberikan dan berada di pundak negara.

Namun, hak atas informasi publik tersebut tentu saja dapat dibatasi pemenuhannya sebagaimana HAM lainnya. Pembatasan terhadap pelaksanaan HAM termasuk hak atas informasi publik ini diatur secara konstitusional melalui Pasal 28J ayat (2) UUD NRI 1945. Tentu saja pembatasan hanya dilakukan dengan tujuan untuk menjamin hak dan kebebasan orang lain serta untuk memenuhi tuntutan yang adil sesuai dengan pertimbangan moral, nilai-nilai agama, keamanan, dan ketertiban umum dalam suatu masyarakat. ${ }^{54}$

Akan tetapi pembatasan tersebut harus seminimal mungkin, yang berarti bahwa tanggung jawab negara dalam memenuhi hak atas informasi publik tetap bersifat terbuka semaksimal mungkin dengan pengecualian yang ketat dan terbatas. Hal ini sesuai dengan prinsip maximum disclosure ${ }^{55}$ yang bermakna bahwa pemberian akses yang seluas-luasnya terhadap informasi publik dengan pengecualian yang ketat dan terbatas. ${ }^{56}$ Dapat dikatakan bahwa prinsip inilah yang kemudian menjadi ratio legis keberadaan Pasal 2 UU KIP.

Pasal 2 ayat (1) dan ayat (2) UU KIP menentukan bahwa setiap informasi publik harus terbuka dan dapat diakses oleh setiap pengguna informasi publik, pengecualian terhadapnya haruslah bersifat ketat dan terbatas. Oleh sebab itu, Pasal 2 ayat (4) UU KIP kemudian menentukan bahwa pengecualian terhadap informasi publik karena ia bersifat rahasia sesuai dengan undang-undang, kepatutan, dan kepentingan umum yang tentu saja perlu didasarkan pada pengujian tentang konsekuensi yang timbul apabila

52 Muhadi, supra note $37 \mathrm{hlm} .10$.

53 Baca lebih lanjut Asshiddiqie, supra note $36 \mathrm{hlm}$. 667-668.

54 Lihat ketentuan Pasal 28J ayat (2) UUD NRI 1945.

55 Selain prinsip ini, ada beberapa prinsip lainnya terkait dengan the public's rights to know, yaitu prinsip kewajiban untuk mempublikasikan informasi kunci, prinsip bahwa bada publik harus mempromosikan pemerintahan yang terbuka, prinsip pembatasan hak informasi publik yang bersifat terbatas dan sempit, prinsip adanya proses untuk memfasilitasi akses terhadap informasi, prinsip biaya yang terjangkau, prinsip keterbukaan bagi kegiatan pengambilan keputusan, prinsip supremasi rezim keterbukaan informasi, serta prinsip perlindungan bagi pembocor rhasia (whistleblower). Baca lebih lanjut note $2 \mathrm{hlm}$. 25-27.

56 Retnowati, supra note $5 \mathrm{hlm} .57$. 
informasi tersebut diberikan kepada masyarakat. Dengan demikian, ketentuan Pasal 2 UU KIP tersebut sesuai dengan prinsip maximum disclousure, dimana semua informasi publik harus dapat diakses oleh masyarakat dan ketentuan ini hanya dibatasi dalam hal-hal dan situasi yang sangat terbatas.

Pengecualian terhadap pemenuhan hak atas informasi tersebut kemudian diatur lebih lanjut dalam Pasal 17 UU KIP. Berdasarkan ketentuan Pasal 17 UU KIP tersebut, informasi publik yang dikecualikan untuk dibuka adalah informasi publik yang apabila dibuka dan diberikan kepada pemohon informasi publik dapat: (1) menghambat proses penegakan hukum; (2) mengganggu kepentingan perlindungan hak atas kekayaan intelektual dan perlindungan dari persaingan usaha tidak sehat; (3) dapat membahayakan pertahanan dan keamanan negara; (4) mengungkapkan kekayaan alam Indonesia; merugikan ketahanan ekonomi nasional; (5) merugikan kepentingan hubungan luar negeri; (6) mengungkapkankan isi akta otentik yang bersifat pribadi dan kemauan terakhir atau wasiat seseorang; dan (7) mengungkap rahasia pribadi.

Terkait praktek pembatasan terhadap pemenuhan hak atas informasi tersebut, Moh. Mahfud MD mencontohkan tentang constitutional review terhadap UU Pemilu yang telah melarang dilakukannya survai dan hitung cepat (quick count) dan pengumumannya dalam waktu tertentu sebelum pemilu. ${ }^{57}$ Dikatakan oleh Mahfud MD bahwa saat ia menjadi ketuanya, Mahkamah Konstitusi pernah membatalkan isi UU Pemilu yang melarang dilakukannya survai dan hitung cepat (quick count) tersebut. ${ }^{58}$ Menurut MK masyarakat memiliki hak untuk memperoleh infomasi, termasuk mengenai hasil survai dan hitung cepat penyelenggaraan pemilu, apalagi melalui metode ilmiah seperti survai dan quick count, sehingga pelarangan dalam bentuk apa pun tidak dibenarkan. Oleh sebab itu MK kemudian menyatakan bahwa pelarangan tersebut melanggar ketentuan pasal 28F UUD NRI Tahun 1945 sehingga harus dinyatakan inkonstitusional. ${ }^{59}$

\section{KESIMPULAN}

Informasi publik merupakan salah satu HAM yang telah diatur secara konstitusional dalam Pasal 28F UUD NRI 1945 yang menjamin hak setiap orang untuk berkomunikasi dan memperoleh informasi dalam rangka mengembangkan pribadi dan lingkungan sosialnya. Lebih dari itu, setiap orang dijamin pula haknya untuk mencari, memperoleh, memiliki, menyimpan, mengolah, serta menyampaikan informasi dengan menggunakan semua jenis saluran yang tersedia. Setidaknya terdapat dua alasan utama mengapa informasi tersebut dijadikan sebagai hak melalui hukum di Indonesia, yaitu pertama, ia merupakan bagian dari HAM yang diakui secara universal sehingga sudah selayaknya dimasukkan sebagai hak yang dilindungi oleh konstitusi Indonesia; kedua, informasi publik lahir sebagai HAM adalah sebagai konsekuensi logis adanya

Al-Faqih, supra note 4 hlm. 9.

58 Ibid.

59 Moh. Mahfud MD, Kedudukan Komisi-Komisi Negara dalam Sistem Ketatanegaraan Kita, dalam ibid hlm. 17-18. 
kewajiban negara untuk mempertanggungjawabkan pelaksanaan tugas dan kewenangannya. Tanggung jawab negara ini timbul karena ia terbentuk berdasarkan perjanjian masyarakat, sehingga ia (pemerintah) hanyalah sebagai mandataris atau wakil dari rakyat, sedangkan kedaulatan adalah di tangan rakyat. Oleh sebab itu, menjadi logis kemudian negara harus dapat mempertanggungjawabkan kinerjanya atas penyelenggaraan pemerintahannya kepada rakyat di mana salah satu salurannya adalah melalui pemenuhan hak atas informasi publik. Adapun tujuan utama keterbukaan informasi publik tersebut adalah untuk memastikan terjaminnya akuntabilitas dan kredibilitas lembaga publik melalui penyediaan informasi dan dokumen sesuai permintaan publik.

Dengan adanya jaminan konstitusional terhadap hak atas informasi sebagai bagian HAM tersebut, konsekuensi yuridisnya adalah timbulnya tanggung jawab negara terhadap pemenuhannya. Oleh sebab itu Pasal 28I ayat (4) UUD NRI 1945 kemudian menentukan bahwa tanggung jawab terhadap pemenuhan HAM termasuk dalam hal ini, hak atas informasi publik, diserahkan kepada negara. Pelaksanaan atas tanggung jawab ini tentu saja tidak sekedar bersifat gugur kewajiban saja, namun di dalamnya terkandung esensi bahwa informasi publik tersebut harus disampaikan dengan baik dan benar baik dari segi prosedur maupun dari segi substansinya. Artinya bahwa tanggung jawab negara tersebut antara lain dengan memberikan informasi yang jujur dan dilakukan secara terbuka dan jujur pula. Pemenuhan informasi publik secara terbuka dan jujur ini pada gilirannya akan berkontribusi dalam rangka mewujudkan tata pemerintahan yang baik (good governance).

Lebih jauh, jaminan konstitusional terhadap hak atas informasi publik yang kemudian diatur lebih lanjut dalam UU KIP adalah sebagai konsekuensi logis dari prinsip demokrasi dan negara hukum yang telah dipilih oleh Bangsa Indonesia. Dikatakan demikian karena hak atas informasi publik yang merupakan bagian dari HAM adalah sebagai salah satu ciri penting dari negara hukum demokratis yang menjunjung tinggi kedaulatan rakyat dalam rangka mewujudkan penyelenggaraan negara yang baik guna memberikan pelayanan prima kepada masyarakat. Sedangkan Pelayanan yang prima kepada masyarakat itu sendiri merupakan sasaran dari good governance, sehingga dapat dikatakan bahwa jaminan dan pemenuhan atas hak keterbukaan informasi publik harus dimaknai sebagai bagian dari upaya membangun good governance.

\section{DAFTAR PUSTAKA}

Addink, GH. Kepemerintahan yang Baik (Utrecht University, 2013).

Asshiddiqie, Jimly. Menuju Negara Hukum yang Demokratis (Jakarta: Sekretariat Jenderal dan Kepaniteraan Mahkamah Konstitusi, 2008).

Azhary. Ilmu Negara: Pembahasan Buku Prof. Mr. R. Krannenburg (Jakarta: Ghalia Indonesia, 1986). 
Hadjon, Philipus M. Perlindungan Hukum bagi Rakyat di Indonesia; Sebuah Studi dan PrinsipPrinsipnya, Penanganannya di Pengadilan dalam Lingkungan Peradilan Umum dan Pembentukan Peradilan Administrasi, edisi khusus ed (Peradaban, 2007).

Harjono. Konstitusi sebagai Rumah Bangsa; Pemikiran Hukum Dr. Harjono, S.H., M.C.L. Wakil Ketua MK (Jakarta: Sekretariat Jenderal dan Kepaniteraan Mahkamah Konstitusi, 2008).

Huda, Ni 'matul. Lembaga Negara dalam Masa Transisi Demokrasi (Yogyakarta: UII Perss, 2007).

-_- Ilmu Negara (Jakarta: Rajawali Pers, 2011).

Kusnardi \& Bintan R Saragih. Ilmu Negara (Jakarta: Gaya Media Pratama, 2000).

MD, Moh Mahfud. Dasar dan Struktur Ketatanegaraan Indonesia (Yogyakarta: Penerbit UII Perss, 1993).

Muhshi, Adam. Teologi Konstitusi; Hukum Hak Asasi Manusia atas Kebebasan Beragama di Indonesia (Yogyakarta: LKiS, 2015).

Saraswati, LG et al. Hak Asasi Manusia; Teori, Hukum, Kasus (Jakarta: Filsafat UI Perss, 2006).

Soehino. Ilmu Negara (Yogyakarta: Liberty, 1998).

Tanya, Bernard L, ahmad nasir \& Paijo Jawa. Teori Hukum; Strategi Tertib Manusia Lintas Ruang dan Generasi (Yogyakarta: Genta Publishing, 2010).

Al-Faqih, MZ. "Komisi Informasi Reposisi dan Penguatannya" in (Yogyakarta: Deepublish, 2017).

Febriananingsih, Nunuk. "Keterbukaan Informasi Publik dalam Pemerintahan Terbuka Menuju Tata Pemerintahan yang Baik" (2012) 1:1 Rechtsvinding 135.

Muhadi. "Hukum Administrasi dan Good Governance" in (Jakarta: Universitas Trisakti, 2010).

Muhshi, Adam. "Teologi Konstitusi; Hak Warga Negara atas Kebebasan Beragama berdasarkan UUD NRI 1945” (2013) II:1 J Konstitusi Pus Kaji Konstitusi Univ Dr Soetomo Surabaya Kerjasama Dengan Mahkamah Konstitusi Repub Indones 7.

Retnowati, Endang. "Keterbukaan informasi publik dan good governance (Antara das sein dan das sollen)" (2012) 17:1 Perspektif 54.

Widodo, Suko. "UU Keterbukaan Informasi Publik antara Harapan dan Kenyataan" (2016) 1:2 KANAL J Ilmu Komun 131.

Muhshi, Adam. Meninjau Ulang Kriteria Legal Standing dalam Hukum Acara MK (Jember, 2016).

"Panduan Mengenal Hak atas Informasi Publik dan Pemolisian", online: 〈https://www.kontras.org/buku/PEMOLISIAN\%200K.pdf〉. 
76 | Pemenuhan Hak atas Informasi Publik sebagai Tanggung Jawab Negara

This page is intentionally left blank 